\title{
Materials for the investigation of historical seismicity in Algeria from the records of past earthquakes
}

\author{
Djillali Benouar \\ Built Environment Research Laboratory, University of Bab Ezzouar (USTHB), \\ Civil Engineering Department, Bab Ezzouar, Alger, Algeria
}

\begin{abstract}
This paper presents some materials relating to the investigation of historical seismicity in Algeria. The historical seismicity in Algeria is imperfectly known: its coverage is discontinuous and its record is grossly deficient. The seismicity of the twentieth century is relatively well documented; however, the further back in time, the harder it becomes to collect data. Even so, important research work in studying the seismicity in Algeria has been made in the past by several studies, notably those by Alexis Perrey, M. Chesneau, F. de Montessus de Ballore, N.N. Ambraseys and J. Vogt. This paper discusses the problems of historical earthquake investigation in Algeria and presents a selection of notable historical earthquakes in the country.
\end{abstract}

Key words Historical seismicity - Algeria

\section{Introduction}

This work discusses some of the most important reported earthquakes that occurred in Algeria since 1365, and the issues involved with their study.

For the early times in Algeria, only one reliable earthquake catalogue for the province of Algiers has been published (Ambraseys and Vogt, 1988), which extends back to the fourteenth century. With regard to regional studies, in Tunisia, the earthquake catalogue compiled by Rothé (1980) dates from 410 but does not contain enough information about the sources used. For Morocco, Ramdani et al. (1988) published a list of historical earthquakes. Mezcua

Mailing address: Dr. Djillali Benouar, Built Environment Research Laboratory, University of Bab Ezzouar (USTHB), Civil Engineering Department, BP 32 El-Alia, Bab Ezzouar, Alger 16111, Algeria; e-mail: dbenouar@yahoo.com and Martinez-Solares (1983) compiled an earthquake catalogue for the Ibero-Maghreb region for the period 500 B.C.-1980.

Alexis Perrey is without any doubt the pioneer in this domain. Perrey published a note on the earthquakes in Algeria (Perrey, 1848) and he continued his publication by notes on earthquakes in Algeria up to 1871 in his annual lists. Later M. Chesneau published in the Annales des Mines, a note on the earthquakes during the period 1716-1887 containing some interesting details (Chesneau, 1892). At the same time, Montessus de Ballore (1892) published some comments on the number of earthquakes felt in Algeria under the title «La France et l'Algérie sismiques». The seismicity of North Africa is also addressed in the book «Les tremblements de terre, géographie sismologique» published by Montessus de Ballore (1906). This book includes a map showing the earthquakes reported in Algeria. During the last century, several notes were published in the Comptes Rendus de l'Académie des Sciences (CRAS) about seismic events in Algeria. A further listing of Algerian earthquakes was published in the Bulletin $d u$ 
Service Météorologique d'Algérie during the period 1889 to 1908. Roussel (1973) listed Algerian earthquakes during the period 1716 to 1970 , to analyse the frequency of the seismicity; he prepared also a map of observed intensities. More recently, Ambraseys and Vogt (1988) published a study on the historical seismicity in the province of Algiers during the period 1365 to 1902, and Guidoboni et al. (1994), in her «Catalogue of ancient earthquakes in the Mediterranean area up to the 10th century», mentions a seismic event, which occurred in Setif (Algeria), known at that time as Sitifis, in 419 A.D. The seismicity of Algeria throughout the 20th century is addressed in detail by Benouar (1994).

\section{The historical period}

The period of interest for historical studies should be extended as back in time as far as the data allow.

The period before 1900 (the pre-instrumental period) has to be studied from macroseismic data. Events are typically characterised by a brief description of the macroseismic field, from the data available today. Events reported in the older national catalogues cannot be included in the parametric date set to be used in seismic hazard assessment where the data used in these events are not sufficient for a reliable analysis. These events were usually not studied in a systematic manner or following a defined and documented methodology; they were generally collected from various authors from different periods. These catalogues were compiled by their authors for the preoccupation of their times and not with the needs of present studies in mind.

\section{General methodology}

This section presents the methodology used to re-evaluate the seismicity of Algeria and adjacent regions. This requires: (i) the retrieval and revision of macroseismic data; (ii) the development of a methodology for the preparation of earthquake catalogues. For historical earthquakes (pre-instrumental events) and even for twentieth century earthquakes for which there are no instrumental data, but for which intensities and radii are available, magnitudes are calculated from macroseismic data (using calibration relationships).

\subsection{Measurement of time, intensity and magnitudes}

In Algeria, as in other countries, the measurement of the exact time of earthquakes, which occurred in different historical periods, is very important for our preoccupations today. Not taking this seriously will affect the catalogue through duplicating events and conflating separated events. Through history, different calendars have been used, which makes the measurement of time of seismic events a complex work.

Destructive earthquakes in Algeria and elsewhere have always caused substantial damage and/or total collapse to adobe and other prevailing types of houses. These structures have shown throughout history a high vulnerability and a very low resistance to seismic loads, and even to heavy rain. As a result of their weakness, maximum intensity in any destructive earthquake in Algeria seems to saturate; that is, at intensity 9 or less on the MSK scale, all adobe houses are destroyed, and thus any settlement or hamlet would be equally, but no more, devastated at higher intensities of the scale. Because the building stock in Algeria has numerous variable characteristics such as age, building materials and structural systems, an extensive investigation has to be carried out to reveal what type of constructions were exposed and what state they were in during the time of each event. Due to certain particularities in the construction materials, the assessment of intensities poses some significant problems.

Another serious problem that arises is the correct interpretation of written accounts according to the historical context of the period concerned. Certainly, exaggerations exist in the sources; usually made to attract more attention to documents, but these are not very difficult to discover, particularly when there is more than one source. The contribution of illustrative photographs to the damage survey, when they exist, is noteworthy. 
Magnitude scales allow the classifying of earthquakes objectively and independently of local ground conditions and environment. For a variety of reasons, many earthquakes in Algeria remain without surface-wave magnitudes or simply without any type of instrumental magnitude. To solve this problem, $M_{s}$ is estimated when possible from semi-empirical relationships between $M_{s}$ and $m b$ or $M_{s}$ and $M_{L}$ (Benouar, 1993). $M_{s}$ for historical earthquakes may also be estimated from the radius of perceptibility $(r 3)$, which is defined as the mean epicentral distance of an area within which the shaking was felt with an intensity equal to or greater than $3 \mathrm{MSK}$, and then using a relationship between $M_{s}$ and $r 3$, or by using a relationship between $M_{s}$ and $I_{0}$ (Benouar, 1993).

The location of macroseismic epicentres is also of great value, in terms of understanding tectonics features, particularly during the period before 1900 as well as for the first half of the 20th century. Macroseismic information provided by the available source documentary materials usually allows relatively accurate location of the epicentral zone.

\section{Macroseismic information (literary sources)}

Documentary source materials are essential for a retrospective reconstruction of the macroseismic field data of past earthquakes. Such materials are found to be available in libraries and archive centres across Algeria and abroad. These archives do not always give full macroseismic information for the historical earthquakes during the period pre-1900. A particular case demonstrating the incomplete macroseismic data of Algeria is that of the city of Algiers. There are very few literary sources and documentary materials referring to destructive events in Algiers. The earthquake damage reported in the few records known to have occurred in the city during the last seven centuries of its history is very infrequent, small and mainly due to relatively large earthquakes originating either on land, away from the site of Algiers, or offshore at a considerable epicentral distance from Algiers.
The earliest known earthquake to have caused loss of lives and considerable damage in Algiers occurred in 1365 (Ambraseys and Vogt, 1988). Earlier authors writing on the subject include Shaw (1743) who discussed «De la fréquence des tremblements de terre en Algérie» in his book «Voyages dans plusieurs provinces de Barbarie».

Many factors influence the content and the survival of macroseismic information. These include site accessibility, geographical position of the region, and density of the population, socio-economic conditions, political and military situations, and building stock characteristics. For instance, during the French colonisation period of Algeria, the lack of macroseismic information for native settlements was obviously conditioned by the censorship imposed by the French administration. To understand better the importance of an earthquake and the macroseismic data contained in the contemporary source documents, it is imperative that retrieved information be carefully analysed in their whole historical context, to avoid serious miscalculations. For many parts of Algeria and other parts of the world with comparable literary production and density of inhabitants, it is well known that the cities, large towns or major settlements constitute the main sources of macroseismic information. In cases when the event occurs within the surroundings of such a town, damage information is more likely to be well reported, while that occurring in remote sites could be left unclear. The scarcity of available macroseismic information obviously makes the catalogue very incomplete.

\section{Notable historical earthquakes in Algeria}

Table I presents a sample of historical earthquakes illustrating the seismic activity in Algeria during the period before 1900 . Both these events and the other known historical earthquakes in Algeria still need to be investigated fully in order to be able to include them in the catalogue and use them with an acceptable degree of reliability in seismic hazard analysis. The locations of the principal places affected are shown in fig. 1. 
Table I. Selected historical earthquakes of note in Algeria (see fig. 1 for location of places).

\begin{tabular}{|c|c|c|c|}
\hline Date & Place & Notes & Reference \\
\hline 419 & Setif & Mentioned by Augustine & Guidoboni et al. (1994) \\
\hline 3 January 1365 & Algiers & Destructive & Ambraseys and Vogt (1988) \\
\hline 10 March 1673 & Algiers & Similar to 1716 event & Ambraseys and Vogt (1988) \\
\hline 3 February 1716 & Algiers & Destructive; many casualties reported & Ambraseys and Vogt (1988) \\
\hline 29 November 1722 & Algiers & Several casualties & Ambraseys and Vogt (1988) \\
\hline 9 October 1790 & Oran & Well documented; 2000 dead. & $\begin{array}{l}\text { Lopez Marinas and Salord } \\
\text { (1990) }\end{array}$ \\
\hline March 1819 & Mascara & $\begin{array}{l}\text { Extensive damage in Mascara; damage } \\
\text { also in Oran }\end{array}$ & Mokrane et al. (1994) \\
\hline 3 March 1825 & Blida & Damage at Blida and Algiers, 7000 dead & Ambraseys and Vogt (1988) \\
\hline 22 November 1851 & Mascara & Damage at Mascara but no deaths & Rothé (1950) \\
\hline 22 August 1856 & Djidjelli & Destructive; tsunami & $\begin{array}{l}\text { Ambraseys (1982), Aucapitaine } \\
\text { (1856), Senarmont (1856), } \\
\text { Glautier (1856) }\end{array}$ \\
\hline 9 March 1858 & Kherba & Damage in Kherba area & Ambraseys et al. (1991) \\
\hline 2 January 1867 & Mitidja & Destructive & $\begin{array}{l}\text { Cochard (1867), Ambraseys and } \\
\text { Vogt (1988) }\end{array}$ \\
\hline 16 November 1869 & Biskra & 200 houses damaged and 30 dead & $\begin{array}{l}\text { Rothé (1950), Roussel (1973), } \\
\text { Ollivier (1870) }\end{array}$ \\
\hline 3 December 1885 & M'sila & $\begin{array}{l}\text { One of the strongest in East Algeria: } \\
33 \text { dead }\end{array}$ & $\begin{array}{l}\text { Rothé (1950), Harbi (2000), } \\
\text { contemporary press reports }\end{array}$ \\
\hline 29 November 1887 & El Kalaâ & At least 331 houses collapsed; 20 dead & $\begin{array}{l}\text { Chesneau (1892), contemporary } \\
\text { press reports }\end{array}$ \\
\hline 15 January 1891 & Gouraya & Heavy damage; 36 dead & $\begin{array}{l}\text { Pomel (1891), Rothé (1950), } \\
\text { Ambraseys and Vogt (1988) }\end{array}$ \\
\hline
\end{tabular}

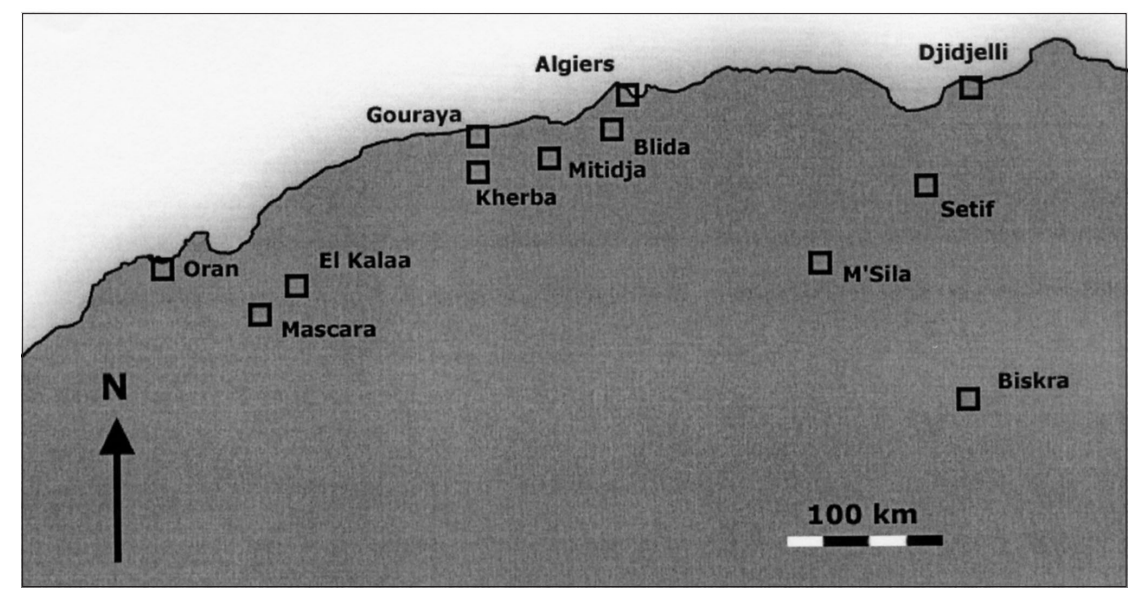

Fig. 1. Location of places mentioned in table I. 


\section{Discussion and conclusions}

The general conclusion is that long-term historical seismicity of Algeria for the period before 1900 is very imperfectly known. The main reasons for this situation are the limited availability and the quality of contemporary documentary records, the prevailing circumstances during the time of the event, the geographical location and problems relating to the intensity. For the period before 1900, the local sources are really the only means of describing the impact of the event for the region, and in the case of nonavailability of such sources, the macroseismic data will remain unknown and thus incomplete. This may explain the apparent low seismic hazard of a number of regions shown on actual modern earthquake hazard maps in Algeria that may not be correct; it may illustrate the absence of long-term observations.

The types of material and the construction techniques during the period before 1900 are different in many respects from today's constructions and thus attributing intensities to such destructive events without taking this into account could be misleading. It may be concluded that the historical seismicity in Algeria remains incomplete, and unknown events during the period before 1900 cannot be included in the earthquake catalogue to be used for seismic hazard analysis.

In Algeria, as in other regions where the seismicity is medium to low, the importance of the role of historical data is most evident. The instrumental period represents only a sample of earthquake activity covering less than 100 years, which can rarely reveal the main features of the region's earthquake activity. For this reason, great and continuous effort should be made to improve the historical data as back in time as possible.

\section{REFERENCES}

Ambraseys, N.N. (1982): The seismicity of North Africa: the earthquake of 1856 at Jijeli, Algeria, Boll. Geofis. Teor. Appl., XXIV, 93, 31-37.

AmbraseYs, N.N. and J. VogT (1988): Material for the investigation of the seismicity of the region of Algiers, Eur. Earthquake Eng., 3, 16-29.

Ambraseys, N.N., J. VogT and R.D. Adams (1991): Seis- micity of the Central Cheliff Valley in Algeria, Publ. Inst. Geogr. Nacion., Ser. Monogr. No. 8, 41-50.

AucApitaine, M. (1856): Note sur le tremblement de terre ressenti en Algérie du 21 au 25 Août 1856, C.R. Acad. Sci., Paris, XLIII, pp. 765.

BENOUAR, D. (1993): The seismicity of Algeria and adjacent regions, during the twentieth century, Ph.D. Thesis (Imperial College of Science, Technology and Medicine, Civil Engineering Dpt., London).

BENOUAR, D. (1994): Materials for the investigations of the seismicity of Algeria and adjacent regions during the twentieth century, Ann. Geofis., XXXVII (4), pp. 416.

Chesneau, M. (1892): Note sur les tremblements de terre en Algérie, Ann. Mines, 9è Sér., I, 5-46.

Cochard, M. (1867): Lettre sur le tremblement de terre d'Alger, adressée par M. Cochard à M. Wolf et communiquée par M. Le Verrier, CRAS, XLIV, pp. 34.

Glautier DE Claubry (1856): Sur les effets du tremblement de terre des 21 et 22 Août 1856 dans certaines parties de l'Algérie, CRAS, XLIII, 589-590.

Guidoboni, E., A. Comastri and G. Traina (1994): Catalogue of the Ancient Earthquakes in the Mediterranean Area up to the 10th Century (ING, RomaSGA, Bologna), pp. 504.

Harbi, A. (2000): Analyse de la séismicité et mise en évidence d'accidents actifs dans le Nord-Est Algérien, Thèse de Magister (IST-USTHB, Alger, Algérie).

Lopez MARINAS, J.M. and R. SALORD (1990): El periodo sismico oranes de 1790 a la luz de la documentacion de los archivos espanoles, Publ. Inst. Geogr. Nacion., Ser. Monogr. No. 6, pp. 64.

Mezcua, J. and J.M. Martinez-Solares (1983): Sismicidad del área Iberomogrebí, Instituto Geográfico Nacional, Madrid, Publ. 203, pp. 301.

Mokrane, A., A. Ait Messaoud, A. Sebai, A. Ayadi and M. Bezzeghoud (1994): Les Séismes en Algérie de 1365 à 1992, Publication du Centre de Recherche en Astronomie, Astrophysique et Géophysique (Département Etudes et Surveillance Sismique, ESS, CRAAG, Alger, Algérie), pp. 277.

Montessus de Ballore, F. (1892): La France et l'Algérie sismiques, Ann. Mines, $9 e ̀$ Sér., I.

Montessus de BAllore, F. (1906): Les tremblements de Terre. Géographie Sismologique (Armand Collin, Paris).

Ollivier, M.E. (1870): Secousses de tremblements de terre à Biskra (Algérie du Sud), du 16 au 19 Novembre inclusivement, CRAS, LXX, 48-51.

Perrey, A. (1848): Note sur les tremblements de terre en Algérie et dans 1'Afrique septentrionale 1845-1846. Mem. Acad. Sci. Arts B. L., Dijon, 299-323.

Pomel, A. (1891): Les tremblements de terre du 15 et 16 Janvier en Algérie, CRAS, CXII, 643-646.

Press Reports in Algeria and France, 1885 and 1887.

Ramdani, M., B. Tadili and T. El Mrabet (1988): The present state of knowledge on historical seismicity of Morocco, in Proceedings of the symposium on Calibration of Historical earthquakes in Europe and Recent Developments in Intensity Interpretation, European Seismological Commission, 23-28 August 1988, Sofia.

Rothé, J.P. (1950): Les séismes de Kherrata et la séismicité de l'Algérie, Bull. Serv. Cart. Geol. Algérie, 4ème Sér., Géophysique, n. 3. 
RothÉ, J.P. (1980): Catalogue des séismes tunisiens (ms.).

Roussel, J. (1973): Les zones actives et la fréquence des séismes en Algérie 1716-1970, Bull. Soc. Hist. Nat. Afrique du Nord, 64 (3), 11-227.
SHAw, M.D. (1743): Voyages dans plusieurs provinces de la Barbarie et du Levant, Neaulme.

SENARMONT, M.H. (1856): Analyse des documents recueillis sur les tremblements de terre ressentis en Algérie du 21 Août au 15 Octobre 1856, CRAS, XLIV, 586-594. 